\title{
The Dance Teaching Research of Pre-school Education in Higher Vocational Colleges
}

\author{
Fu Qiang \\ School of Pre-school Education and Artistic Design, Dalian Vocational and Technical College \\ Dalian, China \\ dalianfuqiang@163.com
}

\begin{abstract}
Dance is our country's compulsory pre-school education vocational colleges, one of which is intended for students in the future engage in pre-work to lay a good foundation of professional, so that with the application of high dance ability, improve their overall quality. This paper describes the dance teaching profession in vocational importance of pre-school, pre-analyzed dance teaching profession in the problems put forward to improve the quality of vocational teaching pre-school education dance countermeasures.
\end{abstract}

Keywords- vocational; pre-school; dance teaching

\section{INTRODUCTION}

With social progress, economic development, family income increases, individuals improving the quality of preschool education as enlightenment aroused widespread concern, to make the full development of pre-school children, we must attach importance to arts education, arts education and dance education is an extremely important part. Nowadays, many vocational colleges teaching pre-school professional dance insufficient attention to teaching objectives are not clear, the importance of teaching students of dance and lack of knowledge of their own learning strengths, resulting in the existence of a wide variety of dance teaching problem. How to train vocational preschool education preschool competent professionals working in the field of specialty, pre-school to adapt to society's demand for highly qualified personnel, we need to conduct in-depth thinking.

Higher vocational pre-school education belongs, also belong to teacher education. Vocational education training goal is a high-level corporate employees and skilled workers, and vocational training objectives pre-school education is to train future early childhood teachers; preschool has both vocational education vocational attributes but also has the characteristics of teacher education. The intrinsic properties of teacher education is normal, generally refers to the professional education of teachers, teacher pre-school education ideology, ethics, code of conduct, professionalism and professional skills of science in school education and a variety of activities concentrated reflection is different from other professional education teacher education essential attribute and particularity lies. Normal sexual connotation pre-school includes not only the future of early childhood pre-school education teacher to get a good early childhood education expertise and practical ability, but also to focus on the future of early childhood teachers with literacy teachers meet the requirements of the times, to continue to achieve their own professional development, exhibit good professional ethics, and ultimately obtain the appropriate professional status. Vocational training pre-school teachers are professional teachers of pre-school teachers, their teaching organizational behavior, teaching methods and activities, the students play a subtle role model, teachers from teaching the details, such as "oral body granted" teaching methods, artistic language of instruction, flexible and diverse forms of teaching and other aspects regulate their own teaching behavior, students make different crafting demonstrations, from teaching to the students to establish a model for their own teaching style and charm affecting students, for their embarked pre-school jobs, pre-school teachers achieve professional basis. Vocational pre-school pre kindergarten teacher charged with cultivation of professional development of education, therefore, necessary requirement for preschool teachers specialized vocational colleges pre-school teacher professionalization.OF

\section{DANCE TEACHING PROFESSION IN THE IMPORTANCE OF PRE-SCHOOL VOCATIONAL}

Dance as vocational colleges Preschool Education a specialized course, the main task of teaching is to train teachers in pre-school education for sustainable development and lay a solid foundation dance theory and professional practice, develop their dance expertise, so that with dance demonstrations, performing, teaching and creating ability, and ultimately improve the overall quality.

Learning to dance for pre-school education students' own vocational development of great significance. Dancing is refined and processed to the body's shape and rhythmic movements as the main means of expression, to express thoughts and feelings of social life and an art form. It is a comprehensive art, both modern cultural life and an indispensable element in self-entertainment, but also on the quality of vocational students in pre-school education an important tool. Students can exercise the will improve the aesthetic, creative thinking ability, and cultivate the spirit of unity and cooperation, cultivate spiritual, physical fitness, and promote the healthy development of their physical and mental.

Higher capacity is pre-school education dance students an important part of professional competence in a variety of 
arts education activities, full use of dance teaching methods in order to better implement the aesthetic education, meanwhile, have a good dance ability also helps teachers and child care and parents communicate. Children people physical and mental development of an important period, there is a strong desire to imitate and plasticity, preschool children learn to dance to make their physical and psychological development of effective, intelligence, thinking ability and physical skills to be an effective workout. Teachers are the best enlightening this period, the parents can not be replaced, an urgent need for the preschool educational psychology with theoretical knowledge, professionalism and skilled singing, dancing, painting and other capabilities of high skill talents. As former professional vocational school students, knowledge structure, quality structure and ability structure to effectively sublimation must pay attention to their psychological development of professional skills and dance.

\section{PRE-SCHOOL EDUCATION DANCE TEACHING VOCATIONAL PROBLEMS}

\section{A. Vocational Students Themselves Bound by the Conditions}

Higher pre-school education students into the school without an interview before the screening system has not received professional training, the students dance on the lower perception, dance feeling is not enough, not strong ability to imitate the dance. Some students never touched even dance, infrastructure is poor, weak economic foundation, these constraints affect the improvement of the quality of teaching dance. Body language is a dance performance art of the primary means of learners; good physical condition is a basic pre-school education dance student's premise. From the perspective of professional dance training in early childhood began studying dance, plasticity stronger, and preschool education for vocational students who are already basically at the adult stage, mostly forming bone. For some of the more difficult movements, such as flexibility, require a higher degree of soft opening dance training, They finished more difficult, so many students of dance training session produced a sense of fear, in the dance learning process, under false pretenses, hastily, and even individual skipping phenomenon. This gave teachers a lot of inconvenience, so that the quality of dance training session is not ideal.

\section{B. The Lack of Standardized Textbook}

Materials is the basis for effective teaching teachers, for teachers better to complete the task of teaching to provide a guarantee, a realistic learning materials can effectively improve efficiency. Unlike pre-school education vocational colleges professional dance academies, dance classes teaching arrangements is relatively small, the current lack of standardized, targeted preschool dance teaching professionals industry reference for teachers and students. Many teachers in vocational institutions to adopt the model of directed teaching, some teachers do not focus on preschool dance training courses and professional distinction.
Copy dance professional institutions teaching materials, teaching content and more difficult, to be completed within a limited class teaching tasks. Had to speed up the progress, course content compression, resulting in poor teaching systematic, science is not strong, is not conducive to preschool students the development of dance training and expertise.

\section{From The Actual Teaching Student Dance CAREER IS NOT STRONG}

Pre-school education dance teaching is to cultivate with a strong dance demonstrations, performances, teaching, and creating capacity in preschool workers, so that they can work on in the future clever use of dance teaching methods, For pre-school children, aesthetic education. Now many vocational colleges for pre-school education dance teaching seriously enough, not very clear teaching objectives, In developing teaching plans and teaching content, some simply stay in the understanding of dance basics and some simple physical exercises on. While others are copying the contents of professional dance training seriously deviated from the pre-school education dance teaching vocational actual situation.. Vocational school arranged some practical courses less single form, only in the trainee and internship before graduation stage to a simple understanding of the work undertaken by preschool, Students usually learned knowledge can not be fully applied to artistic practice, dance a lot of practical ability can not be effectively exercise, which makes pre-school education dance teaching vocational deviated from its original purpose, can not reach students of professional competence purposes.

\section{Higher Vocational PREschool Teaching QUALITY OF PROFESSIONAL DANCE}

\section{A. Pre-school education Student Dance Inspire Motivation}

For preschool children, in the performance of the emotion of each period there are different, also because of their ability to accept individual differences vary, dance is their best mental emotional manifestations learning to dance can fully develop their intelligence, create a beautiful soul. Therefore, the pre-school education dance students must fully understand the importance of learning, clear learning objectives develop and stimulate motivation to learn dance, stronger sense of responsibility and mission. At the same time, to establish a correct concept of early childhood, love children, to grasp the necessary pre-science, psychology and child dance instruction, compose and other professional knowledge, Familiar with the various stages of early childhood basic physiological, psychological characteristics, so that in the future implementation of dance education to fully respect the personality development of young children, according to pre-school education professional features to work.

Cultivate and stimulate students' motivation but also by changing teaching methods and enrich the teaching methods to carry out, in this way can keep teaching interesting, is to train and inspire students to learn an effective indirect method of motivation. Teachers should be carefully designed 
to meet the characteristics of students in teaching programs, such as frequent replacement of teaching music, watch performances, organize competitions, participate in various activities such as artistic practice, teaching full of interesting and enlightening. In order to meet the students and to show themselves to the pursuit of pleasure, and many other needs, and to cultivate and inspire students to learn dance internal motivation.

\section{B. Reasonable Arrangements Pre-school education Dance Teaching Tndividualized}

Teachers teaching content in the dance-depth analysis on the arrangements for vocational students in pre-school education characteristics, to learn other institutions of teaching experience, do not copy rigidly applied, fully integrated with its own teaching experience, vocational preparation suitable for hospital pre-school education student the actual teaching materials and teaching programs.

In the teaching process, according to different students' psychological and physiological characteristics, arrangement of teaching. For pre-school education students, teaching dance through the physical training is the first step to improve the basic conditions for the body, the body language to master basic skills, for the good of dance demonstrations, performance basis. Secondly, for Chinese folk dance, children dance and compose theory, study and practice of skills, enrich their dance vocabulary, comprehensive training students dance performance, dance demonstrations for young children, teaching, compose to make adequate preparations. In addition, teachers in teaching the students should take full account of the different levels, individualized, in all aspects of dance teaching practice activities using excellent, poor portfolio, mutual hand.

\section{Train Students in Pre-school education Dance Comprehensive Ability}

Pre-school education dance teaching, interactive teaching to focus on opening up, the use of three-dimensional theory of teaching, modular teaching and learning autonomy extends to carry out a variety of ways. Teachers experience imitate, collaborative exercises, group show, to observe peer assessment, summarized, and improve extension and other aspects of teaching practice, to stimulate students' enthusiasm for learning, promote student participation inquiry, interactive learning, set "study, and asked, thinking, and distinguish, the line "as a whole, the formation of mutual learning, mutual promotion and common good environment to improve.

Teachers can use their spare time to carry out abundant, rich and diverse cultural activities, but also multi-touch offcampus training practice base, sub-batches arrange nursery preschool students to arts organizations and other agencies to educate trainee, internship and a variety of artistic practice, artistic practice to the students during the practical exercise opportunity for students to actively participate, through the self, self-directed, and acted to deepen their knowledge and understanding of dance. For example, some children so that they dance choreography, in-depth first-line teaching .children to participate in stage performances, etc., through these practices exercise can help pre-school students to recognize their strengths and weaknesses, to stimulate their enthusiasm and creativity to make the students' independent learning skills, teamwork ability, dance performance, "teach, create, play, edit" and other comprehensive practical ability further improved.

\section{Improve the Comprehensive Ability to Artistic Practice}

Pre-school education dance teaching is to enable students to apply their knowledge in future work, so dance classes should pay attention to the practicality of the knowledge granted, focusing on students' comprehensive ability. The student has a certain dance skill, for college students will learn, diligent in thinking, thoughtful features to guide students on the existing knowledge and skills creation exercises to create children rhythm, song performances, dance, dance and dance performances Activities to enable students to exercise in practice, in practice, to get from perceptual knowledge to rational knowledge experience, creative use of existing knowledge and skills of dance, choreography improve ability and innovation ability to apply their knowledge, improve the comprehensive ability. On the one hand, the use of spare time, students will love the art of dance teams organize themselves, through learning, rehearsal excellent dance repertoire, to further improve the performance of their dancing ability. On the other hand, the students 'learning, living, social and other activities as an opportunity to develop students' creativity, to provide students with their own creative space, organize students to creative practice, create their own dance works. After the student has completed the work, organize, guide them to develop rehearsal plan agreed program formats, a clear division of tasks and rehearsals, responsibility to the people, duties, will work in one program unfolded form; according to the needs of work completed production of clothing, props, design stage image, reasonable arrangements for stage lighting and other aspects of content to display in the form of stage performances to the audience, the completion of the whole show. This will not only help students to define the meaning of all aspects of stage performances, master the art practice of the basic law, but also to help students to accumulate experience in theatrical performances, exercise, psychological quality, strengthen the solidarity among students, improve their cohesion, enhance the collective sense of honor. Truly reflects learned to use, learn as I value.

\section{SUMMARY}

The dance is a professional pre-vocational students professional basis of professional competence required course, it is the purpose of teaching is to enable students to master certain knowledge and skills of dance, dance with a certain artistic quality, but more importantly comprehensive ability of students to achieve their social and economic competence of pre-school dance education needs. For preschool education dance teaching vocational obtain good results, we should practicality, according to its training objectives, combined with pre-school education physiological and psychological characteristics of students, to stimulate students' motivation comprehensive, in-depth 
study vocational teaching pre-school dance characteristics, In the course content, methods, means and so bold reforms designed course content, truly easy, step by step, lively, mobilize the enthusiasm of students and inspire students to have missed the play the students' creativity, and improve dance teaching effectiveness, improve the quality of teaching, so that students in vocational pre-school education expertise and cultural awareness be effectively improved, and can skillfully master and use dance teaching methods for students in the future engage in pre-school education work has laid a good foundation.

\section{ACKNOWLEDGMENT}

This research was financially supported by The project of science foundation of education department of Hainan province (No.Hjsk2012-64); National study base in Hainan Province in 2011 planning issues (No.QMZJD2012-12); The 2011 Hainan education science study topics of the "12th Five-Year Plan (No.QJI12540); Supported by Scientific Research Foundation of Qiongzhou University (No. QYQN201307).

\section{REFERENCES}

[1] Ju xiaomeng. Vocational Pre-professional Dance Teaching Reform and Design [J]. Journal of Weifang Educational. 2010 (03): 62-63.

[2] Zhou Qinhui. Preschool Teacher Role of Vocational Preschool Curriculum Reform [J]. Journal of Yunyang Teachers College. 2011 (02) : 127-128.
[3] Liu Limin. Higher Vocational Colleges Vocational Skills of Preprofessional Curricular Reform [J]. Liaoning Higher Vocational Technical Institute Journal. 2011 (04): 62-63.

[4] Ye Haoqin. Currently Before the High Commissioner for Preschool Professional Training Problems and Solutions [J]. Journal of China Women's University. 2011 (06): 98-102.

[5] Qi Haiqin Vocational Non-Normal Probe into Pre-professional Preservice Training [J]. Chinese Vocational and Technical Education. 2009 (29): 74-75.

[6] Li Jing. Discussion Preschool Children Dance Curriculum Design and Reform [J]. Journal of Weifang Educational College. 2010 (04): 6869.

[7] Li Chunchun. University Pre-professional Dance Teaching Problems and Countermeasures [J]. Big stage. 2010 (04): 143.

[8] Wang Xiaojin. On the Dance Teaching on the Importance of Preschool Education [J]. Science \& Technology Information. 2009 (11): 171.

[9] Jia Juan. Shallow Pre-professional Dance teaching Colleges Significance [J]. Swarm text world. 2011 (16): 246.

[10] Gao Yiyi. Of the Particularity of Pre-professional Dance Teaching [J]. Marketing Management Garden. 2011 (08): 212.

[11] Chen Jie. Pre-school Professional Dance Teaching [J]. Journal of Handan College. 2006 (01): 107-108.

[12] Jia Zhu. Multimedia Music Teaching System Application [J]. Key Engineering Materials. Vols. 474-476, pp 1903-1908.2011.

[13] Jia Zhu. MIDI and Music Teaching in Colleges of Multimedia System Application [J]. Key Engineering Materials. Vols. 474-476, pp 19261930.2011

[14] Zhu Jia. Study on National Cultural Structure of Li Nationality Traditional Music Form in HaiNan [J]. Information Engineering Research Institute. Vols. 2, pp 385-38.2012.

[15] Zhu Jia. On the Piano Sustain Pedal Types and Tips [J]. Advances in education research. Vols. 16, pp 309-313.2013. 